\title{
Isolation and Characterization of Amylase from Lysinibacillus Xylanilyticus from Alkaline Environment
}

\author{
Tambekar DH, Tambekar SD ${ }^{1}$, Rajgire AV, Jadhav AS, Sawale KK \\ Post Graduate Department of Microbiology, \\ Sant Gadge Baba Amravati University, Amravati 444602 (India), \\ ${ }^{1}$ Dept. of Microbiology, Dhote Bandhu Science College, Gondia \\ diliptambekar@rediffmail.com
}

\begin{abstract}
The uniqueness of the Lonar Lake water is its salinity and alkalinity. Most of the industrial processes are carried out at high temperature and at high $\mathrm{pH}$ and needs enzyme having high temperature and pH stability. The present study deals with isolation, production and dynamics of amylase from bacterial strain isolated from the alkaline Lonar Lake. Isolation of bacteria was done by using Horikoshi medium and screened for production and partial characterization of amylase. A total of five bacterial cultures were isolated and a bacterial isolate DHT 18 selected for study was characterized by cultural, morphological, biochemical and 16S rRNA gene sequencing resulted it into Lysinibacillus xylanilyticus which showed optimum activity at temperature $60^{\circ} \mathrm{C}$ and pH 10 indicating thermo-stability which is most useful in food, pharmaceutical and detergent industries and can be exploited for biotechnological potential.
\end{abstract}

Keywords: Lonar Lake, Haloalkaliphiles, Bacillus, Amylase

\section{INTRODUCTION}

Natural alkaline environment occurred in Lonar Lake, an Indian soda Lake situated in Lonar, District Buldhana, Maharashtra, India which is a unique basaltic rock meteorite impact crater, ranking third in the world and filled with saline water having an average $\mathrm{pH}$ of 9.5-10 [1]. Haloalkaliphiles, in particular Bacillus species are discovering for their industrial application such as food, pharmaceutical and detergent industries which have ability to produce extracellular enzymes at high $\mathrm{pH}$ and temperature [2]. Microbial enzymes are widely used in industrial processes and $\alpha$-amylase is one of the most important industrial enzymes, having applications in industrial processes such as brewing, baking, textiles, pharmaceuticals, starch processing, and detergents. $\alpha$-amylases are some of the most versatile enzymes in the industrial enzyme sector and account for approximately $25 \%$ of the enzyme market [3]. Strains of Bacillus have been some of the workhorses of enzyme production for decades, mainly because of their ability to overproduce amylase [4]. B. subtilis, B. stearothermophilus, B. licheniformis, and B. amyloliquefaciens are known to be good producers of $\alpha$-amylase, and they have been widely used for commercial production of the enzyme for various applications. These alkaline amylase producing bacteria are of great importance for its high thermo-stability, $\mathrm{pH}$ stability and most important industrial enzymes production $[5,6,7]$. Therefore, attempt was made to study the isolation, production and dynamics of amylase from bacterial strain isolated from the alkaline Lonar Lake.

\section{Materials And Methods}

\subsection{Collection, Enrichment, Isolation and Identification of Amylase Producing Bacteria}

A total of 12 samples of sediment, matt and water were collected from Lonar Lake and transferred to $100 \mathrm{~mL}$ sterilized distilled water in $250 \mathrm{~mL}$ conical flask and agitated $(100 \mathrm{rpm})$ at $37^{\circ} \mathrm{C}$ for $15 \mathrm{~min}$ on rotary shaker. The sample was then heated at $80^{\circ} \mathrm{C}$ for $15 \mathrm{~min}$ to destroy all the vegetative microbial cells. One $\mathrm{mL}$ of each diluted sample was inoculated in Horikoshi medium (A, B, C and D) and incubated at $37^{\circ} \mathrm{C}$ for $72 \mathrm{~h}$ and four time repeated sub-culturing was made in the same medium. After enrichment, culture was inoculated on Nutrient agar ( $\mathrm{pH} \mathrm{10)}$ and incubated at $37^{\circ} \mathrm{C}$ for $24 \mathrm{~h}$ and well distinct colonies were selected and maintained as a stock on nutrient agar slant for screening. Individual bacterial colonies were screened for amylolytic activities on Starch agar medium and zone hydrolysis was recorded. Amylase producer were identified based on morphological, cultural and biochemical characteristics and 16S rRNA gene sequencing of culture was performed at Agharkar Research Institute, Pune. 


\subsection{Amylase Assay}

The $100 \mathrm{~mL}$ Starch nutrient medium was inoculated with culture and incubated for $48 \mathrm{~h}$ at $37^{\circ} \mathrm{C}$ in incubator. After $48 \mathrm{~h}$ incubation, centrifuged the broth at $5000 \mathrm{rpm}$ for $15 \mathrm{~min}$. The supernatant served as crude enzyme source. The standard graph of maltose was prepared using 3,5dinitrosylisilic acid reagent. Estimation of amylase was carried out with $2.5 \mathrm{~mL}$ of (1\%) starch solution; $2.5 \mathrm{~mL}$ of $\mathrm{PO}_{4}$ buffer, $1 \mathrm{~mL}$ of $\mathrm{NaCl}$ and $1 \mathrm{~mL}$ of enzyme in a test tube and incubated in boiling water bath for $5 \mathrm{~min}$ as per DNS method.

\subsection{Characterization of Amylase}

The effect of $\mathrm{pH}$ on alkaline amylase was determined by assaying the enzyme activity at different $\mathrm{pH}$ ranging from 6.0 to 12 , effect of temperature by incubating from $40^{\circ} \mathrm{C}$ to $80^{\circ} \mathrm{C}$ using the $\mathrm{PO}_{4}$ buffer $(0.2 \mathrm{M})$. The effect of substrate concentration on alkaline amylase activity was determined by incubating the reaction mixture for $15 \mathrm{~min}$. with different substrate concentration, ranging from $0.5 \mathrm{mg} / \mathrm{mL}$ to $4 \mathrm{mg} / \mathrm{mL}$. The effect of enzyme concentration on alkaline amylase activity was determined by incubating the reaction mixture ( $\mathrm{pH} \mathrm{10)}$ for $15 \mathrm{~min}$. at different enzyme concentration ranging from $0.5 \mathrm{~mL}$ to $4 \mathrm{~mL}$. The activity of the amylase was then measured as per assay procedure.

\section{RESULTS AND DISCUSSION}

In the present study, a total of 10 different bacterial species were isolated from water, sediment and matt samples from Lonar Lake. Out of 10 , four isolates were showed maximum starch hydrolysis activity on starch agar medium at $\mathrm{pH} 10$. Out of them one isolate DHT18 was selected for further study since it showed prominent amylolytic zone of $23 \mathrm{~mm}$. This isolate was characterized based on cultural, morphological and biochemically by commercially available Hi-media Rapid detection kit. The isolate DHT 18 was Gram positive, long rod shape and motile. Growth was detected at different $\mathrm{pH}$ (7 to 12) and salt concentration of $\mathrm{NaCl}(1$ to $8 \%)$. The growth of isolate DHT 18 was found to be optimum at $50^{\circ} \mathrm{C}$ to $60^{\circ} \mathrm{C}$ temperature. Phylogenetic analysis based on $16 \mathrm{~S}$ rRNA gene sequences indicated that strain DHT18 is Lysinibacillus xylanilyticus.

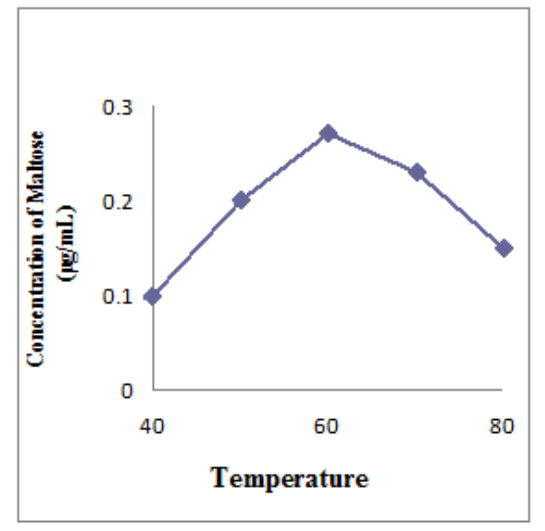

Fig1. Effect of temperature on the activity of

Enzyme Amylase

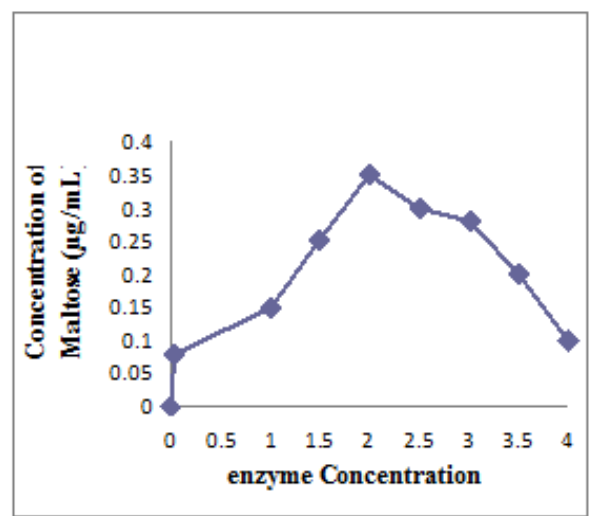

Fig3. Effect of enzyme concentration on the Activity of enzyme Amylase

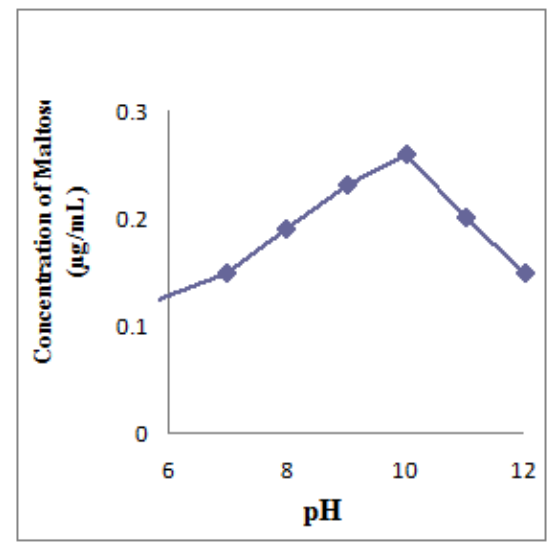

Fig2. Effect of $p H$ on the activity of enzyme Amylase

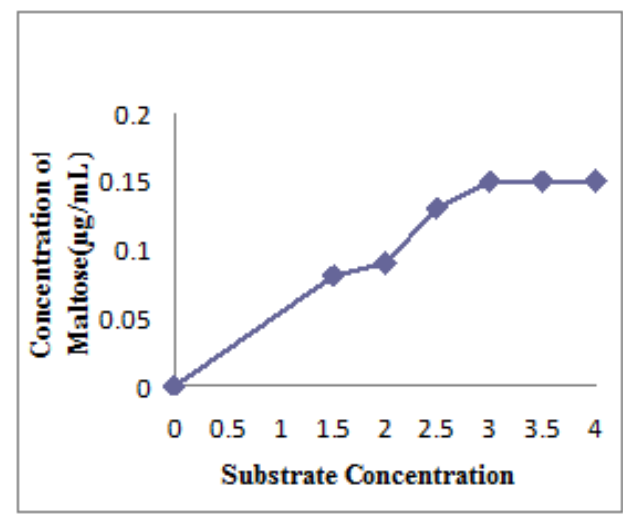

Fig4. Effect of Substrate on the activity of enzyme Amylase 
Isolation and Characterization of Amylase from Lysinibacillus Xylanilyticus from Alkaline Environment

Table1. Cultural, morphological and biochemical characteristics of amylase producing Lysinibacillus xylanilyticus (T) ( FJ477040)

\begin{tabular}{|l|c|l|c|l|c|}
\hline Gram character & + & Glucose & - & $\alpha$-Methyl-D-glucoside & - \\
\hline Shape of Bacteria & LR & Dextrose & + & Rhamnose & - \\
\hline Arrangement of Cell & Single & Galactose & - & Cellobiose & - \\
\hline Spore & + & Raffinose & - & Melezitose & - \\
\hline Motility & + & Trehalose & + & $\alpha$-Methyl-D-mannoside & - \\
\hline Catalase & - & Meliboise & - & Xylitol & - \\
\hline Oxidase & - & Sucrose & - & ONPG & - \\
\hline Voges Proskauer & - & L- Arabinose & - & Esculin hydrolysis & + \\
\hline Citrate utilization & - & Mannose & - & D-Arabinose & - \\
\hline Nitrate reduction & - & Inositol & - & Malonate Utilization & - \\
\hline Arginine & - & Sorbitol & - & Sucrose & - \\
\hline Lactose & - & Mannitol & - & Inulin & - \\
\hline Xylose & - & Adonitol & - & Sodium gluconate & + \\
\hline Maltose & + & Arabitol & - & Glycerol & - \\
\hline Fructose & - & Erythritol & - & Salicin & - \\
\hline
\end{tabular}

Note: $+=$ Positive, $-=$ Negative

From the data it showed that, the maximum amylolytic activity was observed at temperature $60^{\circ} \mathrm{C}$ (Fig.1) and $\mathrm{pH} 10$ (Fig. 2) by Lysinibacillus xylanilyticus. Optimum pH for amylolytic activity of amylase producing bacteria was observed between $\mathrm{pH}$ 8-10.5. The optimum enzyme concentration required for maximum activity of amylase $2 \mathrm{ug} / \mathrm{mL}$ (Fig.3) and substrate concentration was found 1.5 $\mu \mathrm{g} / \mathrm{mL}$ (Fig.4). The isolated bacteria Lysinibacillus xylanilyticus produce the amylase enzyme which has thermophilic, alkalophilic and has potential is used in industry. Same results reported by Singh et $a l$, [8]. Annamalai et al. [9], reported on amylase production at optimum activity was found at 8 and maintained at $\mathrm{pH}$ 11. Tambekar et al.,[10] isolates amylase producing Bacillus sp. and optimum activity was found to be on $50^{\circ} \mathrm{C}, \mathrm{pH} 10$ and substrate concentration $1.5 \mu \mathrm{g} / \mathrm{mL}$ of amylase

Table2. The 16S rRNA gene sequencing closest phylogenetic affiliation, pair similarity and ribosomal database project report of isolated amylase producing organism DHT 18 from Lonar lake

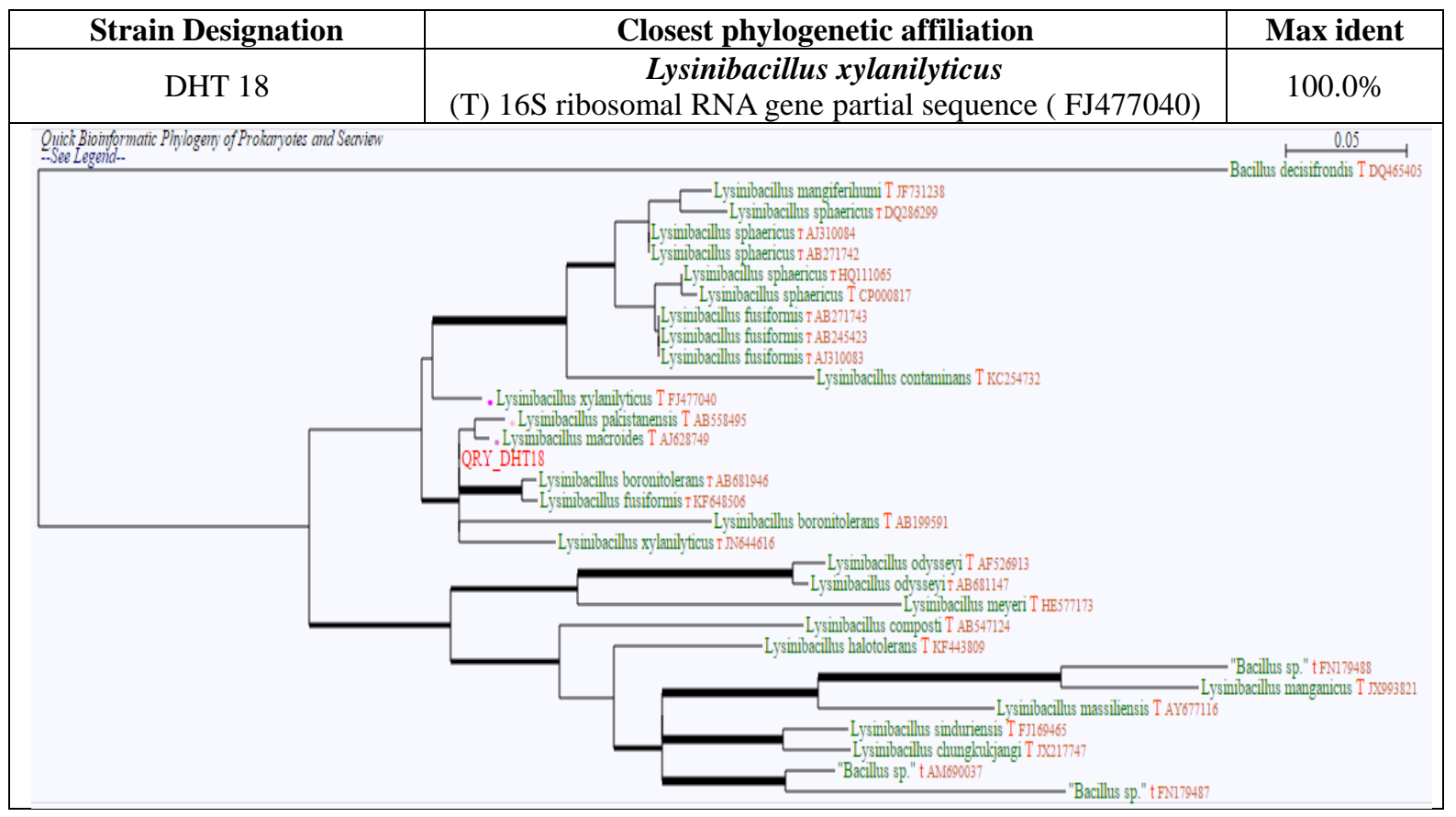

\section{Conclusion}

The haloalkaliphilic Lysinibacillus xylanilyticus isolated from the alkaline Lonar Lake, India and exhibited amylase activity at extremophilic condition. However, novel features of the enzyme such as stability over the wide range of $\mathrm{pH}$ 6-12, temperature $40-80^{\circ} \mathrm{C}$ and salt concentration $0.5-10 \%$ make it an attractive candidate for future studies and development process. The production of the enzyme with these sources would be economically attractive preposition. This is valuable information for enzyme production and optimization by extremophilic Lysinibacillus xylanilyticus. Amylase from 
Lysinibacillus xylanilyticus has bright future towards the improvement and production of novel enzymes for entirely new areas of industrial and biotechnology application.

\section{REFERENCES}

[1] Tambekar DH and Dhundale VR. (2012). Studies on the physiological and cultural diversity of bacilli characterized from Lonar Lake (MS) India. Biosci Disco, 3(1): 34-39.

[2] Joshi AA, Kanekar pp, Kelkar AS, Shouche YS, Wani AA, Borgave SB and Sarnaik SS, (2008). Cultivable bacterial diversity of alkaline Lonar Lake in India. Microb Ecol, 55(2):163-72.

[3] Shanmughapriya S, Kiran GS, Selvin J, Gandhimathi R, Baskar TB, Manilal A and Sujith S. (2009), Optimization, production and partial characterization of an alkaliphilic amylase produced by sponge associated marine bacterium HalobacteriumSalinarum.MMD047. Biotechnology and Bioprocess Engineering, 14: 67-75.

[4] Soenshein AL, Hoch JA and Lasik R (1993). Bacillus subtilis and other Gram-positive Bacteria: Biochemistry, Physiology and Molecular Genetics, ASM, New York.

[5] Borsodi AK, Micsinai A, Rusznyak A, Vladar P, Kovacs G, Toth EM, and Marialigeti K. (2005). Diversity of alkaliphilic and alkali tolerant bacteria cultivated from decomposing reed rhizomes in Hungarian Soda Lake. Microb ecol, 50: 9-18.

[6] Srinivasan TR, Das S, Bal KV, Philip R and Kannan N. (2009). Isolation and characterization of thermostable protease producing bacteria from tannery industry effluent. Recent Res Sci Technol, 1(2), 63-66.

[7] Dhundale VR, More VR, Nagarkarand RD, Hemke VM and Tambekar DH. (2014). Isolation and characterization of a novel amylase from Bacillus pseudofirmus. Indian J.L.Sci, 4 (1): 69-76.

[8] Singh R, Kumar V and Kapoor V (2014). Partial purification and characterization of a heat stable $\alpha$-amylase enzyme from a Thermophilic Actinobacteria, Streptomyces sp. MSC702. Enzyme Res. 10(6):363-368.

[9] Annamalai N, Thavasi R, Vijayalakshmi S and Balasubramanian T (2011). Extraction, purification and characterization of thermostable, alkaline tolerant a-Amylase from Bacillus cereus. Ind J Microbio, 51(4): 424-429.

[10] Tambekar DH, Chandurkar AY and Tambekar SD (2014). Partial characterization and optimization of alkaline Amylase from Bacillus spp. from Lonar Crater. Int J Adv Pharm Biol Chem, 3(2): 481-486. 